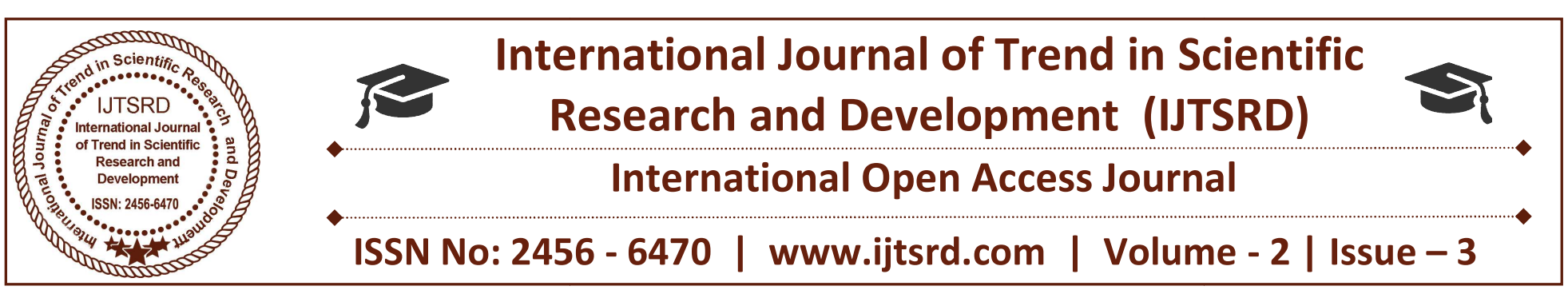

\title{
Growth and Employment Diversification Towards Non Farm Sector in North East: A Brief Overview
}

\author{
Debakshi Bora \\ Research Scholar, Dibrugarh University, Department of Economics, Dibrugarh, Assam, India
}

\section{ABSTRACT}

Structural transformation is defined as the transition of economy from low productivity to high productivity and from low intensive to skill intensive activities. Economic development is often equated with structural transformation of the economy where the relative share of agriculture sector both in national income and labour force declines while that of industrial and services sectors increases. As economy transform from primary to secondary and tertiary sectors, workers also move from one sector to another. Diversification not only changes occupational structure of men Cworkers $/$ but employment status of women workers also. As educational attainment increases among women, this lead to transformation of female employment in an economy from primary to other sectors. North East region of India has been considered as backward region in terms of growth in percapita income. North Eastern economy is basically a rural and agrarian economy. But now a day's more and more people leave agricultural sector and join the non farm sector in the rural economy as a source of livelihood and employment. In this paper an attempt has been made to analyse the role of structural diversification on the status of women employment in North East and examine the factors that effects these diversification. This paper examined the growth of Non Farm sector in North East vis-a-vis India. This paper is based on secondary sources of data collected from various literatures, journals, books, bulletins etc and basically emphasising on Non Farm sector.

Keywords: Employment status, Non farm sector, North East, Structural diversification

\section{INTRUDUCTION}

Structural diversification of an economy explains the sectoral shift in its domestic product. Structural diversification refers to transition of an economy from low productivity to high productivity and from low intensive to high intensive activities. Economic development refers to the structural changes in production and employment pattern which enhances the productivity of labour and earning of workers. Development of an economy associated with a process of structural transformation that entails a falling share of agriculture both in terms of output and employment. As economy develops, sector wise share of Gross Domestic Product (GDP) shift initially from primary to secondary and to tertiary sector. This transformation not only changed production pattern but also changed share of workforce in an economy. One aspect of economic development highlighted by the theoretical and empirical scholarship in development economics is the process of structural transformation. The vast empirical studies of Colin Clark (1990), Fisher (1952) and Simon Kuznets $(1966,19690)$ supported this theory and regarded this sectoral shift as an index of development in developed countries.

Indian economy is a rural agrarian economy. Agriculture is traditionally the most important economic activity of our country. It still holds a very important place in the rural economy both in terms of its contribution to Net National Product and employment generation. Over the years, its growth has stagnated as the sector has limited potential of productively absorbing the growing rural workforce. For example the share of primary sector in GDP in $1950-51$ is $56.7 \%$ and $2000-01$ it was $26.2 \%$ and in 
2014-15 it was $14.9 \%$. The workforce share of primary sector in 1983 was $78 \%$ and $72 \%$ in $1999-2000$ and further it was down to $48.9 \%$ in 2011-12. On the other hand during this period, the workforce share of secondary sector has gone up from $9.4 \%$ to $12 \%$ and then $24.3 \%$. Share of secondary sector in GDP increased from $13.7 \%$ in $1950-51$ to $23.6 \%$ in 2014 15.In the scenario, nonfarm activities have gained significant importance over time. Rural diversification is related to the non farm sector which has been gaining importance in providing gainful employment and additional income opportunities to the growing rural workforce over the years.

North Eastern region considered the "land of Sun Rising" situated at the North Eastern Himalayan sub region of India. North East Region composed of eight states namely Assam, Arunachal Pradesh, Meghalaya, Manipur, Mizoram, Nagaland, Tripura and Sikkim. One of the important features of rural areas of North East India is a relatively large workforce engaged in agricultural sector. The agriculture in India is traditional in nature and using low level of techniques. Large pressure on agricultural land could not absorb workforce productively. In NE large number of rural population are engaged in agriculture. Mono cropping is generally practiced in agricultural field which is characterised by huge underemployment. Agriculture has not been able to generate surplus for investment and augment purchasing power and has field to generate new employment avenues. Moreover factors like frequent occurrence of flood, drought like seasons, large number of small land holdings and fragmented land holdings, unequal land distribution structure are threatening the livelihood sustainability of the rural people. In this context the non farm sector has emerged as an important segment of the rural economy in North East .The rural non farm sector has gained considerable importance now a days as an alternative strategy for generating employment, reducing poverty.

Women in North East are basically engaged in agricultural sector as family labour. Structural changes decrease the participation of women in labour force because women in rural North East are basically not educated. They have engaged themselves in some household stuff such as rearing of children, in some family agricultural work. But now a day's women are become educated. They have also participated in some non agricultural work i.e. they have diversified from primary to secondary sector. The rise in female participation to labour market and the labour reallocation from primary to secondary and tertiary is inevitable for development of an economy. This research paper was mainly focused on diversification from farm to non farm sector.

\section{STATEMANT OF THE PROBLEM:}

The impact of structural diversification varies from negative to positive effects. For example, diversifications lead to withdrawal of critical labour from the family farm and alleviate credit. In developing economics one cannot expect the production and employment structure to move at the same pace. Employment structure changes slowly and gradually in rural areas. Diversification includes changes in the sector to which they are shifted. If emerging changes in the rural non agricultural sector are likely to ensure any stability in employment and income to those rural people, it can be treated as a positive process. On the other hand, if it has resulted in switching permanent agriculture labours to daily wage labour, with low bargaining power for wages other terms of work the shift has been negative process. So, this paper is aimed to analysis the growth of Non Farm sector in India and North East. The main concern of this paper is to discuss the impact of diversification on status of rural employment in North East.

\section{LITERATURE REVIEW:}

Sudan K Falendra (2007) focused on the process of livelihood diversification and women empowerment through self help group and micro credit and its impact under integrated watershed Development Project in Jammu and Kashmir. The author concluded that the introduction of women self micro credit in Jammu and Kashmir is fruitful through the participation approach. This involvement have resulted in increased income and improved livelihood of the beneficiaries.

Mijahid Noorin et.al (2012) explained the that structural change of economic structure from agriculture to industrial and services sector reduce the female labour force participation in case of developing nation. But the activity of female lab force participation has increased in the later age of economic development due to increase in education and dynamics of economic activity. The author used GDP and square for the estimation of $U$ shaped 
relationship between female labour supply and economic growth.

Misra Benara Shuchi (2013) investigated the pre and post reform period trends and patterns of rural non farm sector employment in India and reveals that the sector has growth over a period of time both in terms of generating additional employment opportunities for the rural workforce and also its share as a part of rural NDP. The analysis and findings of this article are based on data from different rounds of surveys conducted by NSSO on employment and unemployment. The author concluded that liberalisation has positive impact on Non Farm employment for rural population.

Mech Annesha (2015) examined the sector wise composition of rural Non Farm employment and its growth in Assam vis-a-vis India and also analysed rural Non Farm employment elasticity at both state and national level. This paper was based exclusively on NSS data on employment and unemployment. The author has used compound annual growth rate method to calculate trends of Non Farm employment in state and national level after reform period. The author concluded that the majority of rural workers are engaged in farm sector but its contribution to GSDP is less in comparison to its participation. Among the Non Farm sector two sector namely community social and personal services sector and trade, hotels and restaurant sector accounts highest share of rural employment in Assam.

Malakar Krishendu (2017) observed in his article discussed the share of women in total labour force participation in NER. The author correlated level of education with the participation rate of women in economic activity. He found that in other developed states of India where female literacy rate is comparatively higher than the stats of NER but, female workforce participation is relatively lower in those states compared to NER.

\section{OBJECTIVES:}

1. To examine the growth of Non farm sector in India and North East.

2. To understand the employment status of male and female in Non Farm sector in North East in comparison with India.

3. To analyse the determinants that influence rural employment diversification.

\section{METHODOLOGY:}

This paper is mainly concerned with assessing the growth and composition of rural Non Farm sector In North East. This paper is based on secondary sources of data collected from various literatures, books, articles report etc. Data collected from various round of NSSO services is used for analysis. Bar diagram, chart, table etc is used for analysing.

\section{DISCUSSION:}

\section{Defining Rural Non Farm Sector:}

Rural Non Farm activities may be defined in a number of different ways. In the background paper for the 1995 World Development Report, Lanjouw and Lanjow (1995) defined the rural non Farm sector as incorporating all economic activities in rural areas except agriculture, livestock, fishing and hunting. Indian scholar have also followed the common convention of including animal husbandry,, hunting and trapping, forestry and logging, fishing etc in agriculture and accordingly, all other economic activities in rural areas as falling within the purview of the RNFS(Chadha 1993). So, Non-farm sector is that sector which includes both household and nonhousehold activities i.e. it is the combination of both secondary and tertiary sector. Some of the examples of non-farm sector are manufacturing, handicrafts, mining and quarrying, transport trade, community and personal services etc. Now a day the need of nonfarm sector is very important especially in the rural areas to increase the level of employment. As per govt. statistics (1998) more than $81.9 \%$ of rural enterprises were non agricultural in nature which includes wide range of activities. Nearly 40 million persons are working in this sector of which $74 \%$ are males.

Since India is an agro based country, so most of its population dependent upon agriculture. In North Eastern region also most of the people earn their livelihood from agricultural sector. But gradually the proportion of land holding portion decreases because of heavy population growth. So the problem of seasonal unemployment, disguised employment arises in the economy. This problem can be solved by shifting the labourers from farm sector to the nonfarm sector. It will also have positive impact on increasing income and employment opportunity which also helps in reducing poverty. 
International Journal of Trend in Scientific Research and Development (IJTSRD) ISSN: 2456-6470

Growth Rate of Rural Non Farm Sector in India:

Table:1

\begin{tabular}{|c|c|c|c|c|c|c|c|c|}
\hline \multirow{3}{*}{ YEAR } & \multicolumn{4}{|c|}{ EMPLOYMENT } & \multicolumn{4}{|c|}{ INCOME } \\
\hline & \multirow{2}{*}{$\begin{array}{l}\text { AGRICULTU } \\
\text { RE }\end{array}$} & \multicolumn{2}{|c|}{ NON AGRICULTURE } & \multirow[t]{2}{*}{ TOTAL } & \multirow{2}{*}{$\begin{array}{l}\text { AGRICULTU } \\
\text { RE }\end{array}$} & \multicolumn{2}{|c|}{ NONAGRICULTURE } & \multirow{2}{*}{$\begin{array}{l}\text { TOT } \\
\text { AL }\end{array}$} \\
\hline & & INDUSTRY & \begin{tabular}{|l} 
SERVICE \\
S
\end{tabular} & & & INDUSTRY & SERVICES & \\
\hline $1972-73$ & 74.58 & 6.75 & 18.67 & 25.42 & 41.01 & 23.34 & 35.65 & 58.99 \\
\hline 1983 & 68.51 & 13.83 & 17.67 & 31.49 & 36.24 & 24.25 & 39.61 & 63.76 \\
\hline $1987-88$ & 64.97 & 15.93 & 19.10 & 35.03 & 31.72 & 25.23 & 43.05 & 68.28 \\
\hline 1993-94 & 63.83 & 15.012 & 21.16 & 36.16 & 30.01 & 25.15 & 44.84 & 69.99 \\
\hline 1999-00 & 60.27 & 16.22 & 23.50 & 39.73 & 24.99 & 25.31 & 49.69 & 75.05 \\
\hline 2004-05 & 56.50 & 18.70 & 24.79 & 43.50 & 20.22 & 26.23 & 53.55 & 79.78 \\
\hline $2009-10$ & 51.76 & 21.93 & 26.30 & 48.23 & 14.5 & 28.1 & 57.4 & 85.5 \\
\hline
\end{tabular}

Source: Various rounds of NSSO data (Borrowed from the table given by Deepak kr. Behera et al.)

The above table showed the picture of share of agriculture and non agricultural sector in employment and income in India both at pre and post reform period. The table clearly reveals that the share of agricultural sector both in employment and income has been decreasing continuously. On the other hand the share of non agricultural sector including industry (secondary) and services (tertiary) sector has been increased both in employment and income. The table reveals that share of agricultural sector in employment during $1972-73$ was $74.58 \%$, which was decreased to $63.83 \%$ during $1993-94$ and become $51.76 \%$ during 2009-10. On the other hand during the same period share of non agricultural sector in employment has been increased from $25.42 \%$ then $36.16 \%$ and 48.23 respectively. The share of agriculture in income has also been seen decreasing from 1972-73(41.01\%) to 2009-10(14.5). On the contrary the share of total non agriculturall in income has been increasing from $58.99 \%$ in $1972-73$ to $85.5 \%$ during $2009-10$.

\section{Growth of Non-Farm Employment in North Eastern Region:}

The majority of people in North East have accepted agriculture as primary occupation. Here an attempt has been made to study the growth of the Non-Farm employment in the North East states with the help secondary at post reform time period.

Table: 2 Region (in percentage)

\begin{tabular}{|l|l|l|}
\hline NSSO ROUNDS & NORTH EAST & INDIA \\
\hline $1993-1994$ & 24.7 & 21.6 \\
\hline $1999-2000$ & 25.2 & 23.7 \\
\hline $2004-2005$ & 26.1 & 27.3 \\
\hline $2009-2010$ & 34.9 & 32.1 \\
\hline
\end{tabular}

Source: NSSO data

Fig: 1

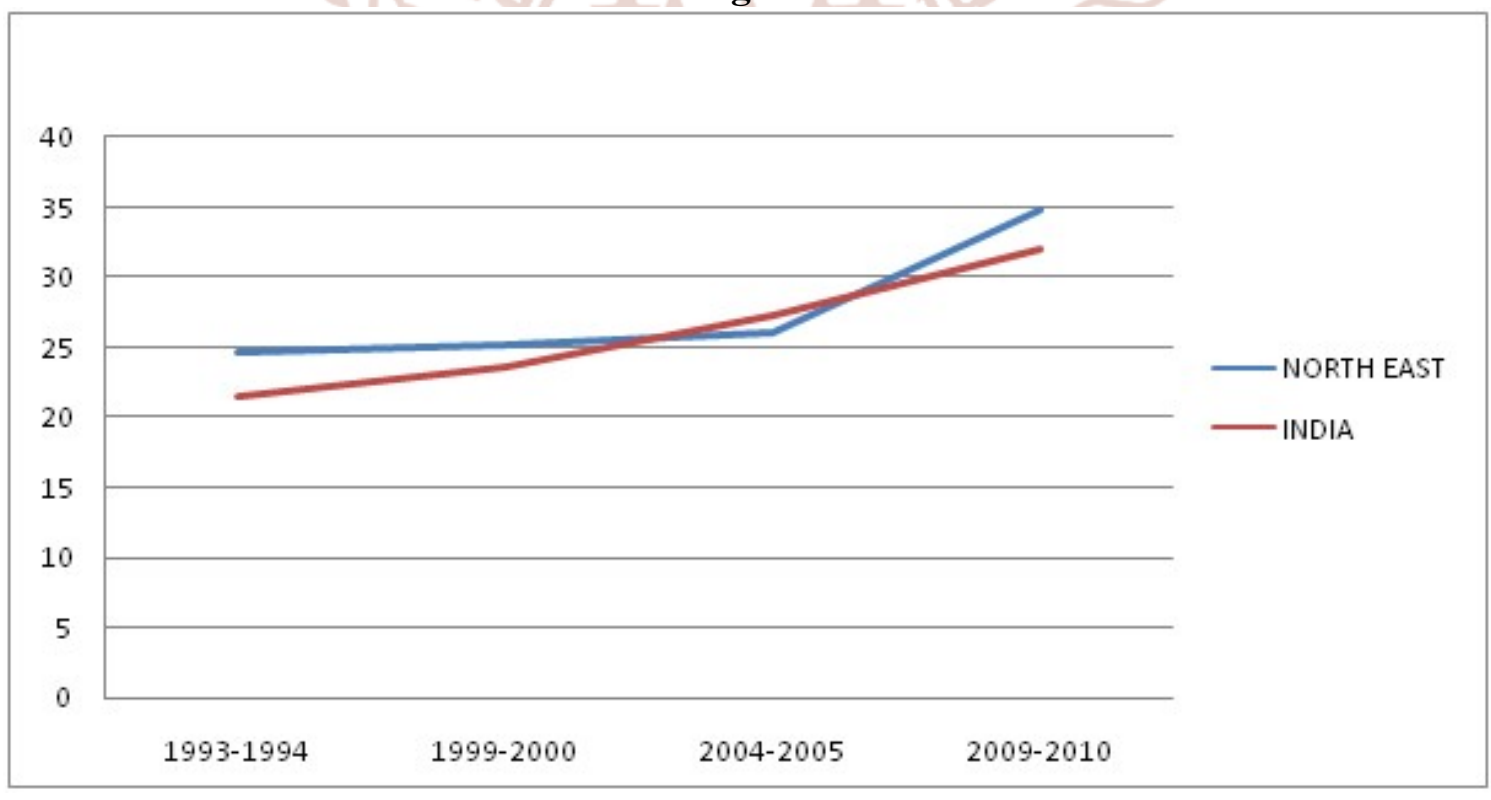

Source: NSSO data, (Borrowed from Chakraborty Kingshuk,2012) 
International Journal of Trend in Scientific Research and Development (IJTSRD) ISSN: 2456-6470

From the table it was seen that the employment generation in the non-farm sector was generally increasing from 1993 to 2010 both in India and in the North Eastern Region. Among that the increasing status of the North Eastern Region was greater than India except in the year 1999-2000. In 1993-94, employment generation in North Eastern Region was $24.7 \%$ and in India it was $21.6 \%$ i.e. employment in NER is greater than India. Again in 1999-2000, the level of employment in NFS was $25.2 \%$ and in India it was $23.7 \%$. Here also employment status in NER is greater than in India. But in 2004-05 employment in non-farm sector in India is greater than NER i.e 27.3>26.1. In 2009-10 NER has greater employment than India i.e. 34.9 in NER and $32.1 \%$ in India. Now we can come to the conclusion that employment status in the non-farm sector in NER is really very satisfactory. It is increasing year after year. Fig:1 showed the differences of rate of growth of Non Farm sector between North east and India during 1993 to 2010 .
State Wise Percentage Share of Rural Non Farm Sector in North Eastern Region:

Table: 3

\begin{tabular}{|l|l|l|l|l|}
\hline States & $\begin{array}{l}1993- \\
94\end{array}$ & $\begin{array}{l}1999- \\
2000\end{array}$ & $\begin{array}{l}2004- \\
2005\end{array}$ & $\begin{array}{l}2009- \\
2010\end{array}$ \\
\hline $\begin{array}{l}\text { Arunachal } \\
\text { Pradesh }\end{array}$ & 13.6 & 16.6 & 18.1 & 24.3 \\
\hline Assam & 20.8 & 32.3 & 25.7 & 29.5 \\
\hline Manipur & 36.2 & 24.7 & 30.7 & 46.1 \\
\hline Meghalaya & 14 & 13.5 & 18.2 & 29.3 \\
\hline Mizoram & 11.1 & 14.5 & 12.6 & 19.4 \\
\hline Nagaland & 25.1 & 20.3 & 20.7 & 25.9 \\
\hline Tripura & 52.4 & 54.3 & 56.8 & 69.4 \\
\hline $\begin{array}{l}\text { North East } \\
\text { Region }\end{array}$ & 24.7 & 25.2 & 26.1 & 35 \\
\hline
\end{tabular}

Source: NSSO, Rounds of 50th, 55th, 61 st and 66th

Now this paper want to analyze what is the percentage share of the 7 states of NER excluding Sikkim in rural non-farm employment for the time period 1993-94: 199-00; 2004-05 and 2009-10. The data is collected from NSSO and we tabulated the data as follows:

From the table it can be summarized that in each and every state of NER the percentage share of rural nonfarm employment is increasing, but the increasing level is different for each state. Tripura has the highest percentage of employment generation in non-farm sector $69.4 \%$ and Mizoram has the lowest percentage $19.4 \%$. But if we consider the variation then Nagaland has less variation i.e. only $0.8 \%$.

Male female distribution of the workforce in Non Farm sector in NER

Table: 4

\begin{tabular}{|c|c|c|c|c|c|}
\hline States & Male/Female & $1993-94$ & $199-200$ & 2004-05 & 2009-2010 \\
\hline \multirow{2}{*}{ Arunachal } & Male & $24.4-1$ & 24.2 & 26.2 & 29.6 \\
\hline & Female & 3.8 & 4.9 & 7.3 & 13.7 \\
\hline \multirow[t]{2}{*}{ Assam } & Male & 21.8 & 35.3 & 30.4 & 33.4 \\
\hline & Female & 16.8 & 20.6 & 11.7 & 13.8 \\
\hline \multirow[t]{2}{*}{ Manipur } & Male & 34 & 22 & 30.6 & 39.3 \\
\hline & Female & 39.7 & 30.4 & 30.9 & 65 \\
\hline \multirow[t]{2}{*}{ Meghalaya } & Male & 17.5 & 14.2 & 20.8 & 30.7 \\
\hline & Female & 9.5 & 12.7 & 15.2 & 26.9 \\
\hline \multirow[t]{2}{*}{ Mizoram } & Male & 13.4 & 14 & 15.2 & 21.2 \\
\hline & Female & 6.6 & 12.5 & 8.9 & 16.4 \\
\hline \multirow[t]{2}{*}{ Nagaland } & Male & 31.5 & 29.5 & 30.4 & 32.4 \\
\hline & Female & 10.7 & 8.1 & 9.6 & 15.3 \\
\hline \multirow[t]{2}{*}{ Tripura } & Male & 4.5 & 54.6 & 57.6 & 64.2 \\
\hline & Female & 43.4 & 50.9 & 51.4 & 86.4 \\
\hline \multirow[t]{2}{*}{ North East } & Male & 28.2 & 27.7 & 30.1 & 35.8 \\
\hline & Female & 18.6 & 20.0 & 19.3 & 33.9 \\
\hline
\end{tabular}

Source: NSSO data 
Fig: 2

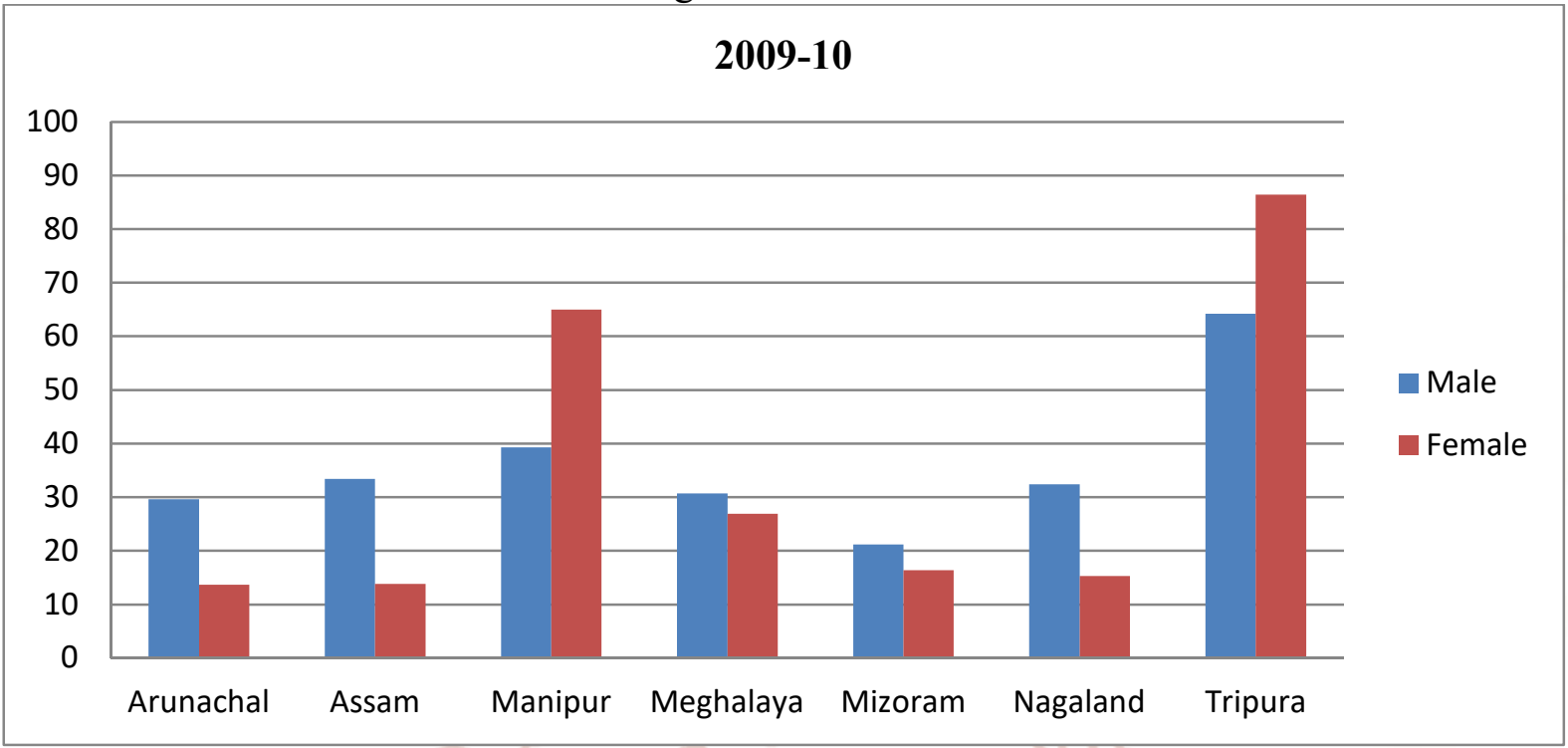

Source: NSSO data

Now the next task is to analyze the gender wise employment growth rate of the rural non-farm sector in the NEF. Here also we use NSSO data.

The table: 4 reveal the data on male female distribution of the workforce in non-farm sector in NER. From the table it is seen that the participation of both male and female increases in each and every state of NER. In Tripura the female participation is very high i.e. $86.4 \%$ and it is higher than male participation i.e. $64.2 \%$. In Manipur also female participation $(65 \%)$ is higher than the male force (39.3\%). In Mizoram although the percentage of female participation increases over time but it is very low in comparison to other states. In Assam the gap between male and female participation is the highest than other states.

In figure: 2, it was revealed that in 2009-10, work force participation of female in Non Farm sector in Manipur and Tripura is higher than male work force participation. On the other hand other states in North East like Arunachal, Assam, Meghalaya, Mizoram and Nagaland male work participation in North East regions higher than female.

The determinants that lead to growth of Non-Farm Sector in the rural area:

\section{Seasonal employment:}

In NER, agriculture is the principal occupation in the rural areas. But agriculture is seasonal in nature in this region. NER gives importance on rice cultivation and there is absence of multi cropping system. They are engaged in the field hardly for 4 months and in the remaining months they can earn their livelihood by joining in different types of non-farm activities.

\section{Prosperity of the agricultural sector:}

This is another one important factor for the growth of the rural non-farm sectors. If the agricultural production is sufficient and accordingly the farmers get remuneration, then they can invest their excess income in non-farm sector so that they can earn some extra income.

\section{Development of infrastructure:}

Infrastructure is the important determinants of growth. People always diversify to the sector where infrastructure is good. So development of suitable infrastructure is a key factor for expansion of nonfarm employment.

\section{Consumption linkages:}

As the income of the people engaged in non-farm sector increases they increase the share of their expenditure in the consumption of the products of non-farm sector. It increases the demand for non-farm sector which further lead to employment generation.

\section{FINDINGS:}

From the analysis we can summarized the findings-

1. The growth of Non Farm sector in India as well as Assam has been increasing especially from economic reform. The rate of increase in NFS in North Eastern region is almost same to the rate in India. 
2. Structural diversification from farm to non-farm sector increases employment level In North East.

3. Among the seven states of North East Region, Tripura has the largest employment generation in non-farm sector and Mizoram has the smallest percentage.

4. Diversification of female to non-farm sector is observed highest in Tripura and lowest in Manipur as per 2010-11 NSSO data.

5. The main determinants of increase in non-farm employment are seasonal unemployment, prosperity of agricultural sector, development of infrastructure and consumption linkages.

\section{LIMITATION OF THE STUDY:}

The main limitation of this study is unavailability of latest data. Due to lake of time the study has used secondary sources of data for analysis. This study shows the brief overview of the scenario of Non Farm sector in North East.

\section{CONCLUSIONS:}

Access to non-farm activities to the rural population will certainly bring about a structural transformation in the rural employment scenario. Thus employment in RNFS should be considered as a viable option to generate additional employment opportunities for the rural workforce, alleviation of poverty, empowering the poor and reducing income disparities (Misra, 2012). This paper tried to explain the glimpse of rural non farm sector and nonfarm employment in North East. This paper has also given a brief picture of gender wise employment growth in Non Farm sector. At all India level the share of employment and income generated from agriculture and allied activities decreased both in the pre and post reform period. The study suggests that rural non farm sector is emerging as one of the key diverse of rural development and transformation in India as well as North East.

\section{ACKNOWLWDGEMENT:}

This my privilege to express a deep sense of gratitude to my respective teacher Dr. Amarjyoti Mahanta, Associate Professor, Department of Economics, Dibrugarh University, Assam and Dr. Debo Kr. Chakraborty, Professor, Department of Economics, Dibruhgarh University, Assam for their continuous guidance and encouragement. I am thankful from my core of the heart to Professor E Bijay Kr. Sign, Manipur University for his beneficial advice. I express my deep sense of gratitude to my parents who are spirit behind this work. I express my sincere thanks to my friend Daisy Basishtha for helping me to write this paper. Without this study may not be completed. I am indebted to my best friend Abhijit Das for his continuous support in every step of my life.

\section{REFERENCES:}

1. Majnula.K,(2002), "Diversification in Employment Structure and status of Rural Women's workers in Ernakulam District", $\mathrm{PhD}$ thesis submitted to the Cochin University of Science and Technology.

2. Ranjan Sharad (2006), “Occupational Diversification and Access to rural Employment: Revisitingthe Non Farm Employment Debate" MPRA paper no. 7870 .

3. Behera $\mathrm{Kr}$ Deepak (2011), “ Structural Transformation in India: An Econometric Investigation" Sample Registration System, Ministry of Home Affairs, New Delhi.

4. Chakraborty Kingshuk, (2012), “ An investigation in to status of rural non farm sector and its impact on the rural economy", Thesis submitted to Gauhati University.

5. Misra Benara Shuchi (2013), " Growth of Rural Non Farm Employment in India: Pre and Post Reform Trends and Patterns" Journal of Land and Rural Stusies, 1(2),99-112

6. D'souza Alwin(2014), "Structural Transformation in the North Eastern Region of India: Charting out an agriculture-based development policy", Discussion paper in economics, Center for international trade and development, JNU, Delhi.

7. Mech Annesha (2015), “ Growth and Composition of Rural Non Farm Employment in Assam: A post reform scenario", Journal of Business Management and Social Science Research, ISSNO,2319-5614,vol 4,No-12

8. Malakar Krishnendu (2017), Women in Labour force in North Eastern States", International journal of Applied Research, 2017;3(4) 